\title{
Relationship Between Serum Total Carbon Dioxide Concentration and Bicarbonate Concentration in Patients Undergoing Peritoneal Dialysis
}

Keiji Hirai ${ }^{1}$, Susumu Ookawara ${ }^{1}$, Momoko Matsuyama ${ }^{1}$, Taisuke Kitano ${ }^{1}$, Kiyonori Ito ${ }^{1}$, Yuichiro Ueda 1 , Tatsuro Watano ${ }^{2}$, Shinji Fujino ${ }^{2}$, Kiyoka Omoto ${ }^{2}$, Yoshiyuki Morishita ${ }^{1}$

1. Division of Nephrology, First Department of Integrated Medicine, Saitama Medical Center, Jichi Medical University, Saitama, JPN 2. Department of Laboratory Medicine, Saitama Medical Center, Jichi Medical University, Saitama, JPN

Corresponding author: Keiji Hirai, keijihirai@kfy.biglobe.ne.jp

\section{Abstract \\ Background}

Few studies have assessed the relationship between serum total carbon dioxide $\left(\mathrm{CO}_{2}\right)$ and bicarbonate ion $\left(\mathrm{HCO}_{3}{ }^{-}\right)$concentration in patients undergoing peritoneal dialysis. We determined the agreement between serum total $\mathrm{CO}_{2}$ and $\mathrm{HCO}_{3}{ }^{-}$concentration and the diagnostic accuracy of serum total $\mathrm{CO}_{2}$ for the prediction of low $\left(\mathrm{HCO}_{3}{ }^{-}<24 \mathrm{mEq} / \mathrm{L}\right)$ and high $\left(\mathrm{HCO}_{3}{ }^{-} \geqslant 24 \mathrm{mEq} / \mathrm{L}\right)$ bicarbonate concentrations in patients on peritoneal dialysis.

\section{Methods}

We collected 245 samples of venous blood from 51 patients on peritoneal dialysis. Independent factors that correlated with the $\mathrm{HCO}_{3}{ }^{-}$concentration were analyzed using multiple linear regression analysis. The diagnostic accuracy of serum total $\mathrm{CO}_{2}$ was evaluated by receiver operating characteristic (ROC) curve analysis and a $2 \times 2$ table. Agreement between serum total $\mathrm{CO}_{2}$ and $\mathrm{HCO}_{3}{ }^{-}$concentration was assessed by Bland-Altman analysis.

\section{Results}

Serum total $\mathrm{CO}_{2}$ was independently correlated with $\mathrm{HCO}_{3}{ }^{-}$concentration $(\beta=0.354, p<0.001$ ). The area under the curve of serum total $\mathrm{CO}_{2}$ for the identification of low and high bicarbonate concentrations was 0.909. The diagnostic accuracy of serum total $\mathrm{CO}_{2}$ for the prediction of low and high bicarbonate concentrations was: sensitivity, $91.5 \%$; specificity, $74.7 \%$; positive predictive value, $53.5 \%$; negative predictive value, $96.5 \%$; and accuracy, $78.8 \%$. Bland-Altman analysis showed a moderate agreement

Review began 02/04/2021 Review ended 03/22/2021 Published 03/25/2021

\section{() Copyright 2021}

Hirai et al. This is an open access article distributed under the terms of the Creative Commons Attribution License CC-BY 4.0., which permits unrestricted use, distribution, and reproduction in any medium, provided the original author and source are credited. between serum total $\mathrm{CO}_{2}$ and $\mathrm{HCO}_{3}^{-}$concentration.

\section{Conclusion}

Serum total $\mathrm{CO}_{2}$ correlated closely with the $\mathrm{HCO}_{3}{ }^{-}$concentration in patients undergoing peritoneal dialysis. Serum total $\mathrm{CO}_{2}$ might be useful for predicting low and high bicarbonate in peritoneal dialysis patients.

Categories: Nephrology

Keywords: serum total carbon dioxide, bicarbonate, peritoneal dialysis

\section{Introduction}

Metabolic acidosis is a commonly observed complication in patients with chronic kidney disease (CKD), including those undergoing peritoneal dialysis, and is associated with bone mineral loss, protein energywasting, insulin resistance, and higher mortality risk [1-4]. It also contributes to a rapid decline in residual renal function [5]. Therefore, early detection and accurate diagnosis of metabolic acidosis is important to preserve residual renal function and improve prognosis in patients undergoing peritoneal dialysis.

In Japan, blood-gas analyzers are available in most hospitals. Therefore, bicarbonate ion $\left(\mathrm{HCO}_{3}{ }^{-}\right)$measured using arterial/venous blood gas samples has been widely used for the assessment of metabolic acidosis in peritoneal dialysis patients [6]. A lower $\mathrm{HCO}_{3}{ }^{-}$concentration has been reported to be associated with 
increased mortality in patients undergoing peritoneal dialysis [7]. Because the $\mathrm{HCO}_{3}{ }^{-}$concentration is an important predictor of mortality, a specific device measurement and syringe are necessary, in addition to the blood samples used for blood-gas analyses [8].

The serum total carbon dioxide $\left(\mathrm{CO}_{2}\right)$ concentration represents the total amount of carbon dioxide in the serum. It can be readily measured, along with creatinine, urea, and electrolytes, using a biochemical analyzer in clinical settings [9]. Furthermore, serum total $\mathrm{CO}_{2}$ has been shown to be correlated strongly with the

$\mathrm{HCO}_{3}{ }^{-}$concentration in both patients with CKD not undergoing renal replacement therapy [10] and patients undergoing hemodialysis [11]. However, few studies have investigated the relationship between serum total $\mathrm{CO}_{2}$ and the $\mathrm{HCO}_{3}{ }^{-}$concentration in patients undergoing peritoneal dialysis. We analyzed the relationship between serum total $\mathrm{CO}_{2}$ and the $\mathrm{HCO}_{3}{ }^{-}$concentration in peritoneal dialysis patients.

\section{Materials And Methods \\ Ethics approval}

The study was approved by the ethics committee of Saitama Medical Center, Jichi Medical University (S17052), and was conducted according to the principles contained within the Declaration of Helsinki. The requirement of informed consent was waived and an opt-out method was used because of the retrospective design of the study.

\section{Participants}

Inclusion criteria were: (i) age >20 years; (ii) CKD stage G5D; (iii) regular peritoneal dialysis; (iv) simultaneous measurement of serum total $\mathrm{CO}_{2}$ and $\mathrm{HCO}_{3}{ }^{-}$concentrations. Exclusion criteria were: (i) hemodialysis and (ii) renal transplantation.

\section{Study design}

This was a single-center, retrospective, cross-sectional study. We analyzed the patient data obtained from medical records from the Division of Nephrology, Saitama Medical Center, between April 2017 and March 2019. The laboratory data of blood tests and venous blood-gas tests obtained simultaneously were used for analyses. The relationship between serum total $\mathrm{CO}_{2}$ and the $\mathrm{HCO}_{3}{ }^{-}$concentration was analyzed using Pearson's correlation coefficient. Independent factors correlated with the $\mathrm{HCO}_{3}{ }^{-}$concentration were analyzed using multiple linear regression analysis. The diagnostic accuracy of serum total $\mathrm{CO}_{2}$ for low and high bicarbonate was analyzed using receiver operating characteristic (ROC) curve analysis and a $2 \times 2$ table. The correlation between serum total $\mathrm{CO}_{2}$ and $\mathrm{HCO}_{3}{ }^{-}$concentration was analyzed using Bland-Altman analysis.

\section{Laboratory methods}

Blood and urinary parameters were determined by the Department of Clinical Laboratory, Saitama Medical Center. Samples of venous blood were collected in EDTA-containing tubes from the antecubital vein in all patients and centrifuged within 15 minutes to obtain serum. Serum total $\mathrm{CO}_{2}$ was measured within 15 minutes after centrifugation using an automated biochemical analyzer (JCA-BM6070; JEOL, Tokyo, Japan), as were biochemical parameters (hemoglobin, total protein, serum albumin, blood urea nitrogen, serum creatinine, sodium, potassium, chloride, calcium, phosphate, magnesium, and glucose). Serum total $\mathrm{CO}_{2}$ was determined by an enzymatic method using a commercial kit (Toyobo, Osaka, Japan) in an automated biochemical analyzer. Total weekly urea clearance $(\mathrm{Kt} / \mathrm{V})$ was measured by calculating the sum of the residual renal and peritoneal clearances of urea and converting this to a weekly value [12]. Residual renal urea clearance was determined using 24-hour urine urea divided by plasma urea concentration. Total body water volume was estimated from height, weight, age, and gender using Watson's formula [13].

Samples of venous blood for gas analyses were collected in a heparinized blood-gas syringe from the brachial vein simultaneously with samples for other blood tests and analyzed within 10 minutes to obtain values for $\mathrm{pH}$ and the partial pressure of carbon dioxide $\left(\mathrm{pCO}_{2}\right)$. The $\mathrm{pH}$ and $\mathrm{pCO}_{2}$ of blood were measured using a blood-gas analyzer (Rapidlab-1265; Siemens Healthcare Diagnostics, Tarrytown, New York). The $\mathrm{HCO}_{3}{ }^{-}$ concentration was calculated from measured $\mathrm{pH}$ and $\mathrm{pCO}_{2}$ using the Henderson-Hasselbalch equation [14]: $\mathrm{pH}=6.1+\log \left(\left[\mathrm{HCO}_{3}{ }^{-}\right] / \mathrm{pCO}_{2} \times 0.03\right)$.

\section{Statistics}

Statistical analyses were performed using JMP v11 (SAS Institute, Cary, North Carolina). Continuous variables were expressed as mean \pm standard deviation when they were normally distributed and as median 
and interquartile range when non-normally distributed. Categorical variables were expressed as numbers and percentages. The peritoneal dialysis duration was not normally distributed; therefore, this variable was transformed using a natural logarithm. The relationships between two variables were evaluated using Pearson's correlation coefficient. Linear regression analysis was used to identify parameters that independently correlated with $\mathrm{HCO} 3$ - concentration. The parameters that significantly correlated with $\mathrm{HCO}_{3}{ }^{-}$concentration in simple linear regression analyses were included in subsequent multiple linear regression analysis. The diagnostic accuracy of serum total $\mathrm{CO}_{2}$ was determined using ROC curve analysis and a $2 \times 2$ table. The area under the curve (AUC), sensitivity, specificity, positive predictive value, negative predictive value, and accuracy were calculated for the identification of low $\left(\mathrm{HCO}_{3}{ }^{-}<24 \mathrm{mEq} / \mathrm{L}\right)$ and high

$\left(\mathrm{HCO}_{3}{ }^{-} \geqslant 24 \mathrm{mEq} / \mathrm{L}\right)$ bicarbonate concentrations. The cut-off value for $\mathrm{HCO}_{3}{ }^{-}$was set at $24 \mathrm{mEq} / \mathrm{L}$ based on a previous study [15]. Agreement between serum total $\mathrm{CO}_{2}$ and $\mathrm{HCO}_{3}{ }^{-}$concentration was assessed using the Bland-Altman method. $\mathrm{P}<0.05$ was considered to represent statistical significance.

\section{Results}

\section{Patient characteristics}

Patients' characteristics and medications are shown in Table 1. A total of 245 blood samples from 51 patients (35 males and 16 females, mean age $62.3 \pm 13.6$ years, mean peritoneal dialysis duration $27.5 \pm 29.6$ months) were obtained. Forty-one patients (80.4\%) were on continuous ambulatory peritoneal dialysis (CAPD), 33 patients (64.7\%) on automated peritoneal dialysis (APD), and 23 patients (45.1\%) on a combination of CAPD and APD. The mean total weekly Kt/V was $1.68 \pm 0.39$. Thirty-three percent of the patients had diabetes mellitus. The proportions of the patients receiving each medication were: corticosteroid, 3.9\%; $\beta$-blocker, $43.1 \%$; renin-angiotensin system inhibitor, $72.5 \%$; aldosterone receptor antagonist, $7.8 \%$; loop diuretic, 64.7\%; thiazide diuretic, 39.2\%; tolvaptan, $29.4 \%$; potassium binder, $0.0 \%$; phosphate binder, $82.4 \%$; vitamin D analog, $54.9 \%$; calcimimetic, $21.6 \%$; and sodium bicarbonate $0.0 \%$. Calcium concentrations of each peritoneal dialysis solution were as follows: icodextrin solution, $1.75 \mathrm{mmol} / \mathrm{L}$; lactate-buffered solution, $1.25 \mathrm{mmol} / \mathrm{L}$; and bicarbonate-buffered solution $1.25 \mathrm{mmol} / \mathrm{L}$. 


\section{Cureus}

Number of patients

Number of samples

Age (year)

Gender male (number, \%)

Body mass index $\left(\mathrm{kg} / \mathrm{m}^{2}\right)$

Peritoneal dialysis duration (month)

CAPD (number, \%)

APD (number, \%)

CAPD and APD (number, \%)

Icodextrin solution (number, \%)

Lactate-buffered solution (number, \%)

Bicarbonate-buffered solution (number, \%)
51

245

$62.3 \pm 13.6$

35 (68.6)

$22.7 \pm 3.6$

$18.2[9.8-33.7]$

41 (80.4)

33 (64.7)

$23(45.1)$

28 (54.9)

14 (27.5)

37 (72.5)

17 (33.3)

2 (3.9)

22 (43.1)

37 (72.5)

4 (7.8)

33 (64.7)

20 (39.2)

15 (29.4)

$0(0.0)$

42 (82.4)

28 (54.9)

$11(21.6)$

$0(0.0)$

$0.65 \pm 0.11$

$1.68 \pm 0.39$

$0.69 \pm 0.43$

$1.00 \pm 0.30$

\section{TABLE 1: Patient characteristics and medication}

Abbreviations: APD, automated peritoneal dialysis; CAPD, continuous ambulatory peritoneal dialysis; Kt/ $\mathrm{V}$, urea clearance. Valuables are shown as mean \pm standard deviation, median [interquartile range], or number $(\%)$.

Relationship between serum total $\mathrm{CO}_{2}$ and $\mathrm{HCO}_{3}{ }^{-}$concentration

Figure 1 shows the correlation between serum total $\mathrm{CO}_{2}$ and $\mathrm{HCO}_{3}{ }^{-}$concentration. Serum total $\mathrm{CO}_{2}$ was correlated with $\mathrm{HCO}_{3}^{-}$concentration significantly and closely $(\mathrm{r}=0.80 ; \mathrm{p}<0.001)$. 


\section{Cureus}

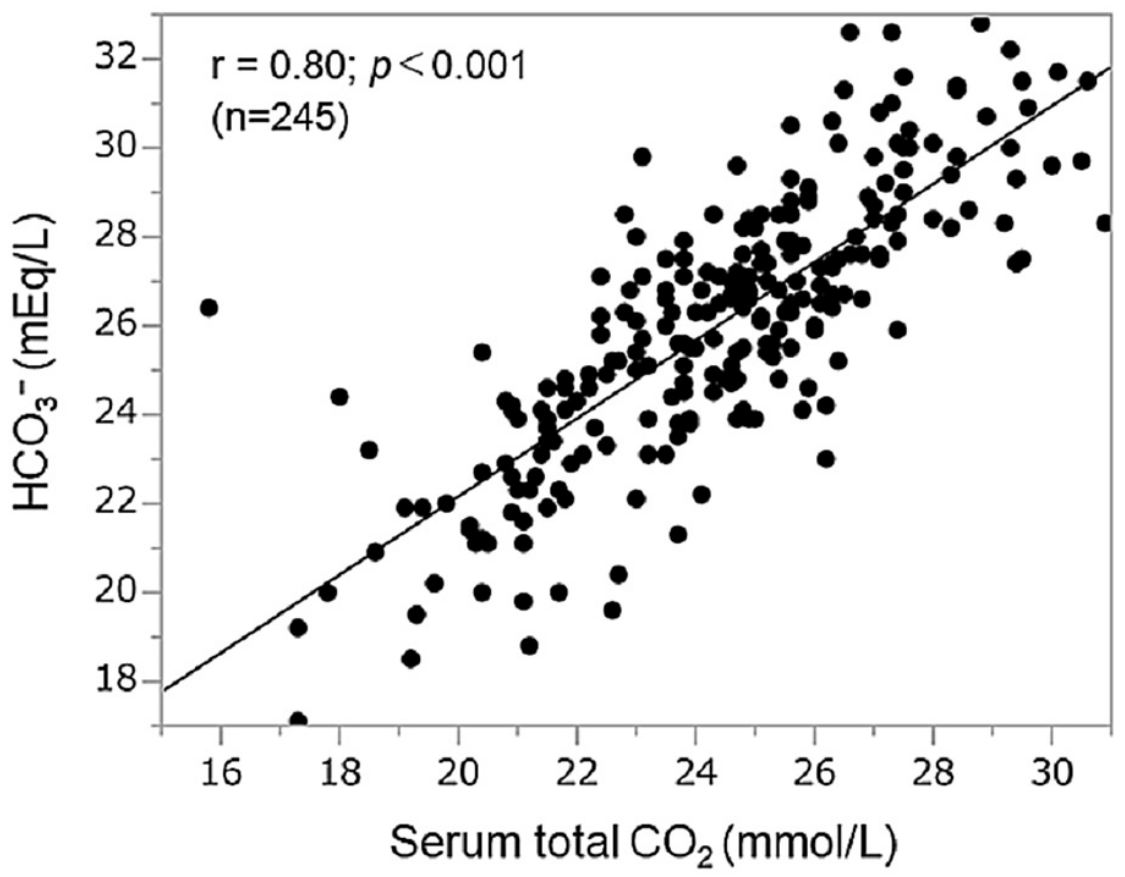

FIGURE 1: Relationship between serum total $\mathrm{CO} 2$ and $\mathrm{HCO}-$ concentration

CO2: carbon dioxide; $\mathrm{HCO} 3-$ bicarbonate ion

\section{Factors correlated with $\mathrm{HCO}_{3}{ }^{-}$concentration}

Simple linear regression analyses showed that $\mathrm{HCO}_{3}{ }^{-}$concentration was significantly negatively correlated with gender male, body mass index, serum albumin, blood urea nitrogen, creatinine, uric acid, sodium, potassium, chloride, phosphate, and magnesium, and with the use of a bicarbonate-buffered solution, phosphate binder, and vitamin $\mathrm{D}$ analog. $\mathrm{HCO}_{3}{ }^{-}$concentration was also significantly positively correlated with diabetes mellitus, four-hour dialysate/plasma creatinine, total weekly Kt/ $\mathrm{V}$, peritoneal weekly Kt/V, total calcium, and serum total $\mathrm{CO}_{2}$, and with the use of CAPD, CAPD and APD, icodextrin solution, lactatebuffered solution, loop diuretic, thiazide diuretic, and tolvaptan. Multiple linear regression analysis was performed using the variables that showed significant correlations with $\mathrm{HCO}_{3}{ }^{-}$concentration in simple linear regression analyses (Table 2 ). This analysis revealed that total weekly $\mathrm{Kt} / \mathrm{V}$ (standard coefficient $[\beta]=$ $0.119, p=0.027)$, serum albumin $(\beta=-0.171, p=0.007)$, blood urea nitrogen $(\beta=-0.138, p=0.011)$, sodium $(\beta=0.352, p<0.001)$, chloride $(\beta=-0.629, p<0.001)$, total calcium $(\beta=0.204, p<0.001)$, phosphate $(\beta=-$ $0.155, \mathrm{p}=0.006)$, and serum total $\mathrm{CO}_{2}(\beta=0.354, \mathrm{p}<0.001)$ were independently correlated with $\mathrm{HCO}_{3}^{-}$ concentration.

Parameter
Age (year)
Gender male (yes vs. no)
Body mass index (kg/m²)
Log-peritoneal dialysis duration (month)
CAPD (yes vs. no)
APD (yes vs. no)
CAPD and APD (yes vs. no)

Simple linear regression analysis

Standard coefficient

0.083

$-0.235$

$-0.194$

0.018

0.353

$-0.114$

0.189

0.20

$<0.001$

0.002

0.08

0.003

0.78
$P$ value

$-0.006$

$<0.001 \quad 0.007$

0.91

0.087

Multivariate linear regression analysis

Standard coefficient

$P$ value

0.09

0.91

0.11 


\section{Cureus}

\begin{tabular}{|c|c|c|c|c|}
\hline Icodextrin solution (yes vs. no) & 0.242 & $<0.001$ & -0.122 & 0.06 \\
\hline Lactate-buffered solution (yes vs. no) & 0.242 & $<0.001$ & 0.002 & 0.97 \\
\hline Bicarbonate-buffered solution (yes vs. no) & -0.242 & $<0.001$ & 0.000 & --- \\
\hline Diabetes mellitus (yes vs. no) & 0.214 & $<0.001$ & 0.072 & 0.15 \\
\hline Corticosteroid (yes vs. no) & 0.112 & 0.08 & & \\
\hline$\beta$-blocker (yes vs. no) & 0.058 & 0.37 & & \\
\hline Renin-angiotensin system inhibitor (yes vs. no) & 0.012 & 0.85 & & \\
\hline Aldosterone receptor antagonist (yes vs. no) & 0.013 & 0.84 & & \\
\hline Loop diuretic (yes vs. no) & 0.289 & $<0.001$ & 0.052 & 0.43 \\
\hline Thiazide diuretic (yes vs. no) & 0.256 & $<0.001$ & 0.016 & 0.76 \\
\hline Tolvaptan (yes vs. no) & 0.165 & 0.010 & -0.070 & 0.22 \\
\hline Potassium binder (yes vs. no) & 0.000 & --- & & \\
\hline Phosphate binder (yes vs. no) & -0.131 & 0.041 & 0.040 & 0.46 \\
\hline Vitamin D analog (yes vs. no) & -0.173 & 0.007 & 0.049 & 0.22 \\
\hline Calcimimetic (yes vs. no) & 0.075 & 0.24 & & \\
\hline Four-hour dialysate/plasma creatinine & 0.293 & $<0.001$ & 0.008 & 0.88 \\
\hline Total weekly Kt/V & 0.138 & 0.031 & 0.119 & 0.027 \\
\hline Renal weekly Kt/V & -0.031 & 0.63 & & \\
\hline Peritoneal weekly Kt/V & 0.160 & 0.012 & -0.092 & 0.05 \\
\hline Total protein (g/dL) & -0.112 & 0.08 & & \\
\hline Serum albumin (g/dL) & -0.206 & 0.001 & -0.171 & 0.007 \\
\hline Hemoglobin (g/dL) & -0.040 & 0.54 & & \\
\hline Blood urea nitrogen $(\mathrm{mg} / \mathrm{dL})$ & -0.481 & $<0.001$ & -0.138 & 0.011 \\
\hline Creatinine (mg/dL) & -0.134 & 0.037 & -0.014 & 0.83 \\
\hline Uric acid (mg/dL) & -0.295 & $<0.001$ & -0.016 & 0.71 \\
\hline Sodium (mEq/L) & -0.185 & 0.004 & 0.352 & $<0.001$ \\
\hline Potassium (mEq/L) & -0.301 & $<0.001$ & 0.025 & 0.66 \\
\hline Chloride (mEq/L) & -0.550 & $<0.001$ & -0.629 & $<0.001$ \\
\hline Total calcium (mg/dL) & 0.283 & $<0.001$ & 0.204 & $<0.001$ \\
\hline Phosphate (mg/dL) & -0.514 & $<0.001$ & -0.155 & 0.006 \\
\hline Magnesium (mg/dL) & -0.180 & 0.005 & -0.014 & 0.76 \\
\hline Blood glucose (mg/dL) & 0.094 & 0.14 & & \\
\hline Serum total $\mathrm{CO}_{2}(\mathrm{mmol} / \mathrm{L})$ & 0.805 & $<0.001$ & 0.354 & $<0.001$ \\
\hline
\end{tabular}

TABLE 2: Simple and multiple linear regression analyses of the parameters correlating with HCO3- concentration

Abbreviations: APD, automated peritoneal dialysis; CAPD, continuous ambulatory peritoneal dialysis; $\mathrm{CO} 2$ : carbon dioxide; $\mathrm{HCO} 3-$, bicarbonate ion; Kt/V, urea clearance; Log, logarithm 


\section{Cureus}

\section{high bicarbonate concentrations}

The ROC curve of serum total $\mathrm{CO}_{2}$ for detecting low $\left(\mathrm{HCO}_{3}{ }^{-}<24 \mathrm{mEq} / \mathrm{L}\right)$ and high $\left(\mathrm{HCO}_{3}{ }^{-} \geqslant 24 \mathrm{mEq} / \mathrm{L}\right)$ bicarbonate concentrations is shown in Figure 2. The AUC was 0.909 , and the optimal cut-off value was 23.7 $\mathrm{mmol} / \mathrm{L}$. The $2 \times 2$ tables, stratified according to serum total $\mathrm{CO}_{2}$ and $\mathrm{HCO}_{3}{ }^{-}$concentration for low and high bicarbonate, are shown in Table 3. The diagnostic accuracy measures of serum total $\mathrm{CO}_{2}$ for the prediction of low and high bicarbonate concentrations were as follows: sensitivity (91.5\%), specificity ( $74.7 \%)$, positive predictive value (53.5\%), negative predictive value (96.5\%), accuracy ( $78.8 \%)$, pre-test probability $(24.1 \%)$, positive post-test probability (53.5\%), and negative post-test probability $(3.5 \%)$.

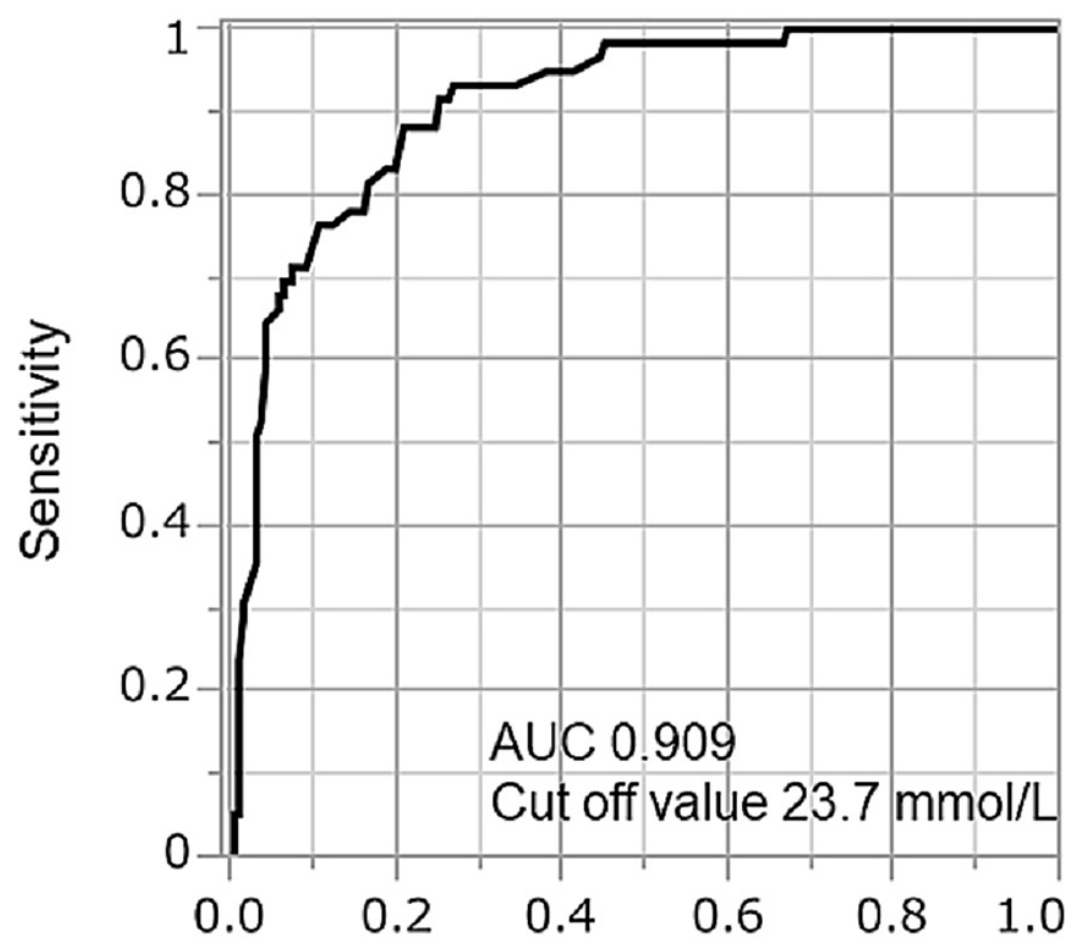

1-Specificity

FIGURE 2: ROC curve of serum total $\mathrm{CO} 2$ for detecting low bicarbonate (HCO3- $<24 \mathrm{mEq} / \mathrm{L}$ ) and high bicarbonate (HCO3- $\geq 24 \mathrm{mEq} / \mathrm{L}$ ) concentrations

AUC: area under the curve; $\mathrm{CO} 2$ : carbon dioxide; $\mathrm{HCO}$-: bicarbonate ion; $\mathrm{ROC}$ : receiver operating characteristic 


\section{Cureus}

\begin{tabular}{|c|c|c|c|c|}
\hline & & \multicolumn{2}{|l|}{$\mathrm{HCO}_{3}{ }^{-}$} & \multirow[b]{2}{*}{ Total } \\
\hline & & $\begin{array}{l}\text { Low bicarbonate }\left(\mathrm{HCO}_{3}^{-}<24\right. \\
\mathrm{mEq} / \mathrm{L})\end{array}$ & $\begin{array}{l}\text { High bicarbonate }\left(\mathrm{HCO}_{3}{ }^{-} \geq 24\right. \\
\mathrm{mEq} / \mathrm{L})\end{array}$ & \\
\hline \multirow{2}{*}{$\begin{array}{l}\text { Serum total } \\
\mathrm{CO}_{2}\end{array}$} & $\begin{array}{l}\text { Low serum total } \mathrm{CO}_{2} \text { (Serum total } \mathrm{CO}_{2}<24 \\
\mathrm{mmol} / \mathrm{L} \text { ) }\end{array}$ & 54 & 47 & 101 \\
\hline & $\begin{array}{l}\text { High serum total } \mathrm{CO}_{2} \text { (Serum total } \mathrm{CO}_{2} \geq 24 \\
\mathrm{mmol} / \mathrm{L} \text { ) }\end{array}$ & 5 & 139 & 144 \\
\hline Total & & 59 & 186 & 245 \\
\hline
\end{tabular}

TABLE 3: $2 \times 2$ table stratified according to serum total $\mathrm{CO} 2$ and $\mathrm{HCO} 3-$ concentration for low and high bicarbonate

Abbreviations: $\mathrm{CO} 2$, carbon dioxide; $\mathrm{HCO}-$, bicarbonate ion

\section{Correlation between serum total $\mathrm{CO}_{2}$ and $\mathrm{HCO}_{3}{ }^{-}$concentration}

Bland-Altman analysis showed moderate agreement between serum total $\mathrm{CO}_{2}$ and $\mathrm{HCO}_{3}{ }^{-}$concentration. The mean difference was $-1.64 \pm 3.66$, and $95.1 \%$ of the points were included within the limits of agreement (the mean difference between the two methods \pm 2 standard deviation [95\% confidence interval]) (Figure 3).

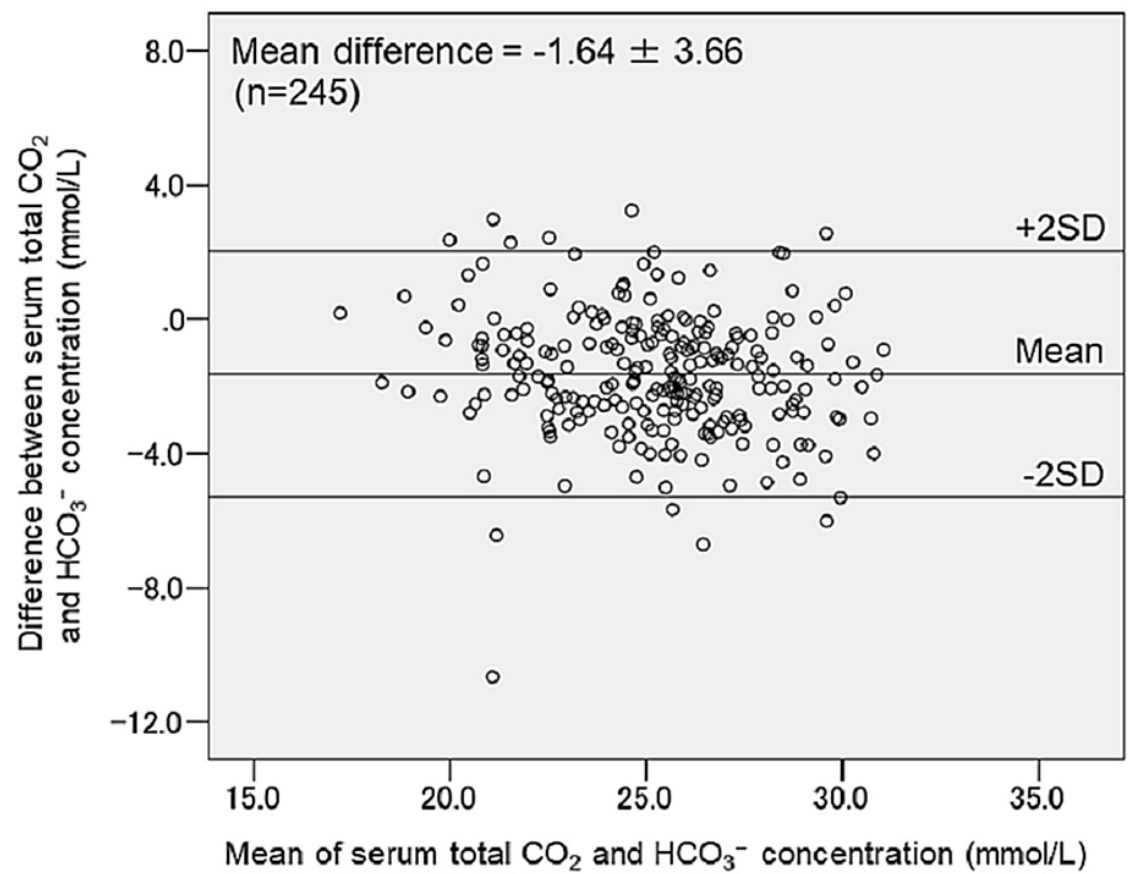

FIGURE 3: Bland-Altman plot comparing serum total $\mathrm{CO} 2$ and $\mathrm{HCO}-$ concentration

CO2: carbon dioxide; $\mathrm{HCO}-$-: bicarbonate ion; SD: standard deviation

\section{Discussion}

In the present study, we investigated the relationship between serum total $\mathrm{CO}_{2}$ and $\mathrm{HCO}_{3}{ }^{-}$concentration in 
peritoneal dialysis patients and found that serum total $\mathrm{CO}_{2}$ closely correlated with $\mathrm{HCO}_{3}{ }^{-}$concentration. We also found that serum total $\mathrm{CO}_{2}$ has high diagnostic accuracy for predicting low bicarbonate and high bicarbonate in peritoneal dialysis patients.

Serum total $\mathrm{CO}_{2}$ is a total concentration of all forms of $\mathrm{CO}_{2}$ in a serum sample, including $\mathrm{HCO}_{3}{ }^{-}$, carbonate, and dissolved $\mathrm{CO}_{2}$. Serum total $\mathrm{CO}_{2}$ value is known to be approximately equivalent to $\mathrm{HCO}_{3}{ }^{-}$concentration because most of $\mathrm{CO}_{2}$ exists as $\mathrm{HCO}_{3}{ }^{-}$in blood [9]. In fact, serum total $\mathrm{CO}_{2}$ has been reported to have a close correlation with $\mathrm{HCO}_{3}{ }^{-}$concentration in both pre-dialysis CKD patients [10] and hemodialysis patients [11]. However, a discrepancy between serum total $\mathrm{CO}_{2}$ and $\mathrm{HCO}_{3}{ }^{-}$concentration is sometimes observed, and temperature and acidity [16] are considered one of the causes of discrepancy in patients without renal impairment [17]. In the present study, serum albumin, calcium, chloride, sodium, phosphate, blood urea nitrogen, and total weekly $\mathrm{Kt} / \mathrm{V}$ in addition to serum $\mathrm{CO}_{2}$ were independently correlated with $\mathrm{HCO}_{3}^{-}$ concentration in serum.

Serum albumin represents the nutritional status of patients and is reportedly associated with dietary protein intake in peritoneal dialysis patients [18]. Protein intake is associated with metabolic acidosis because amino acids into which dietary proteins are broken down release hydrogen ions [19]. Increased serum albumin was reported to be associated with metabolic acidosis in pre-dialysis CKD patients [20]. The weak acidity of albumin has also been considered as the cause of this phenomenon [21]. These findings are consistent with our result, showing a negative correlation between serum albumin and $\mathrm{HCO}_{3}{ }^{-}$concentration.

It has been reported that $\mathrm{HCO}_{3}{ }^{-}$was positively correlated with calcium concentration in hemodialysis patients [22]. In the present study, $\mathrm{HCO}_{3}{ }^{-}$concentration was positively correlated with calcium concentration in peritoneal dialysis patients. These findings suggest that serum $\mathrm{HCO}_{3}{ }^{-}$concentration might be positively correlated with calcium concentration in patients with end-stage renal disease. There were differences in calcium concentrations among peritoneal dialysis solutions used in the present study. The possibility remains that these differences might affect the results of our study.

$\mathrm{HCO}_{3}{ }^{-}$concentration has been shown to decrease along with an increase in chloride concentration through following equilibrium with $\mathrm{HCl}$ and $\mathrm{NaHCO}_{3}: \mathrm{H}^{+}+\mathrm{Cl}^{-}+\mathrm{Na}^{+}+\mathrm{HCO}_{3}^{-}=\mathrm{Na}^{+}+\mathrm{Cl}^{-}+\mathrm{H}_{2} \mathrm{CO}_{3}$ [23]. In the present study, chloride concentration was negatively correlated with $\mathrm{HCO}_{3}{ }^{-}$concentration, which is consistent with the findings of previous reports [10-11].

A cross-sectional study of peritoneal dialysis patients reported that sodium concentration was lower in patients with $\mathrm{HCO}_{3}{ }^{-}<22 \mathrm{mEq} / \mathrm{L}$ than in patients with $22 \leqslant \mathrm{HCO}_{3}{ }^{-}<28 \mathrm{mEq} / \mathrm{L}[24]$. In the present study, sodium concentration was positively correlated with $\mathrm{HCO}_{3}{ }^{-}$concentration. These results suggest that sodium concentration is positively associated with $\mathrm{HCO}_{3}{ }^{-}$concentration in peritoneal dialysis patients.

Phosphate and blood urea nitrogen were shown to be associated with daily protein intake in patients with end-stage renal disease [25]. Protein intake is negatively associated with bicarbonate, as the amino acids into which dietary proteins are broken down release hydrogen ions [19]. Phosphate and blood urea nitrogen were reported to be negatively correlated with bicarbonate in peritoneal dialysis patients [24], which is consistent with the findings of our study.

Currently available peritoneal dialysis fluids contain alkaline anions of $35-40 \mathrm{mmol} / \mathrm{L}$ as lactate or/and bicarbonate [6]. The influx of alkaline anions from the peritoneal dialysis fluid into the blood occurs during peritoneal dialysis because the alkaline anion concentration in serum is usually lower than that in peritoneal dialysis fluid [24]. A previous study reported that dialysis adequacy assessed by daily $\mathrm{Kt} / \mathrm{V}$ was positively correlated with serum bicarbonate level [26]. In the present study, the total weekly Kt/V was positively correlated with $\mathrm{HCO}_{3}{ }^{-}$concentration. These results suggest that peritoneal dialysis dose-dependently increases serum $\mathrm{HCO}_{-}$- concentration caused by the influx of bicarbonate from the peritoneal dialysis fluid into the blood.

In the present study, serum total $\mathrm{CO}_{2}$ was closely correlated with $\mathrm{HCO}_{3}{ }^{-}$concentration and showed high accuracy for the differentiation of low or high bicarbonate concentrations. Therefore, serum $\mathrm{CO}_{2}$ may be a good predictor of bicarbonate concentration and useful to predict whether this is low or high. However, the correlation between serum total $\mathrm{CO}_{2}$ and $\mathrm{HCO}_{3}{ }^{-}$concentration in the present study $(\beta=0.323$ ) was weaker as compared with that of hemodialysis patients $(\beta=0.858)$ [11]. The number of clinical parameters 
correlated with $\mathrm{HCO}_{3}{ }^{-}$concentration was greater in the present study than in the previous one [11] (eight vs three), which might explain the lower correlation between serum total $\mathrm{CO}_{2}$ and $\mathrm{HCO}_{3}{ }^{-}$in this study. The correlation between serum total $\mathrm{CO}_{2}$ and $\mathrm{HCO}_{3}{ }^{-}$concentration might be attenuated in peritoneal dialysis patients. Further studies are necessary to confirm the close correlation between serum total $\mathrm{CO}_{2}$ and $\mathrm{HCO}_{3}{ }^{-}$ concentration and the usefulness of serum total $\mathrm{CO}_{2}$ for the diagnosis of low or high bicarbonate concentrations in peritoneal dialysis patients.

The measurement of serum total $\mathrm{CO}_{2}$ has two advantages as compared with blood-gas analyses. First, the cost of a blood gas-syringe can be saved and the amount of blood required will be reduced using serum total $\mathrm{CO}_{2}$ instead of a blood-gas test. Second, serum total $\mathrm{CO}_{2}$ can be used to predict low bicarbonate and high bicarbonate without the use of a blood-gas analyzer. Therefore, the measurement of serum total $\mathrm{CO}_{2} \mathrm{Could}$ reduce some of the burden on peritoneal dialysis patients and laboratory staff.

Our study had four limitations. First, it was a retrospective, observational study; therefore, selection bias could not be completely eliminated. Second, the study was performed at a single center, which limits the external validity of the results. Third, the study cohort was small, which restricts the generalizability of our findings. Fourth, we used venous blood samples for the analyses. The results might have been different if arterial blood samples had been used. Therefore, further prospective, large-scale, multicenter studies are necessary to confirm our findings.

\section{Conclusions}

Serum total $\mathrm{CO}_{2}$ correlated closely with $\mathrm{HCO}_{3}{ }^{-}$concentration in peritoneal dialysis patients. Serum total $\mathrm{CO}_{2}$ might be useful for predicting low and high bicarbonate in peritoneal dialysis patients.

\section{Additional Information \\ Disclosures}

Human subjects: Consent was obtained or waived by all participants in this study. Ethics committee of Saitama Medical Center, Jichi Medical University issued approval S17-052. Animal subjects: All authors have confirmed that this study did not involve animal subjects or tissue. Conflicts of interest: In compliance with the ICMJE uniform disclosure form, all authors declare the following: Payment/services info: All authors have declared that no financial support was received from any organization for the submitted work. Financial relationships: All authors have declared that they have no financial relationships at present or within the previous three years with any organizations that might have an interest in the submitted work. Other relationships: All authors have declared that there are no other relationships or activities that could appear to have influenced the submitted work.

\section{Acknowledgements}

We thank all staff members of the Department of Clinical Laboratory (Saitama Medical Center, Jichi Medical University, Saitama, Japan) for their excellent work and support.

\section{References}

1. Cochran M, Wilkinson R: Effect of correction of metabolic acidosis on bone mineralisation rates in patients with renal osteomalacia. Nephron. 1975, 15:98-110. 10.1159/000180501

2. Stein A, Moorhouse J, Iles-Smith H, et al.: Role of an improvement in acid-base status and nutrition in CAPD patients. Kidney Int. 1997, 52:1089-95. 10.1038/ki.1997.433

3. Garibotto G, Sofia A, Russo R, et al.: Insulin sensitivity of muscle protein metabolism is altered in patients with chronic kidney disease and metabolic acidosis. Kidney Int. 2015, 88:1419-1426. 10.1038/ki.2015.247

4. Chang TI, Oh HJ, Kang EW, et al.: A low serum bicarbonate concentration as a risk factor for mortality in peritoneal dialysis patients. PLoS One. 2013, 8:e82912. 10.1371/journal.pone.0082912

5. Liu XY, Gao XM, Zhang N, et al.: Oral bicarbonate slows decline of residual renal function in peritoneal dialysis patients. Kidney Blood Press Res. 2017, 42:565-574. 10.1159/000479641

6. Nakayama M, Kawaguchi Y, Akiba T, et al.: A new peritoneal dialysis fluid for Japanese patients: a randomized non-inferiority clinical trial of safety and efficacy. Clin Exp Nephrol. 2017, 21:895-907. 10.1007/s10157-016-1346-9

7. Raikou VD, Kyriaki D: Mortality and low serum bicarbonate level in patients on hemodiafiltration versus peritoneal dialysis. Indian J Nephrol. 2018, 28:105-112. 10.4103/ijn.IJN_232_16

8. O'Leary TD, Langton SR: Calculated bicarbonate or total carbon dioxide?. Clin Chem. 1989, 35:1697-1700. 10.1093/clinchem/35.8.1697

9. Dobson GP, Veech RL, Hoeger U, Passonneau JV: Enzymatic determination of total CO2 in freeze-clamped animal tissues and plasma. Anal Biochem. 1991, 195:232-237. 10.1016/0003-2697(91)90322-k

10. Hirai K, Minato S, Kaneko S, et al.: Approximation of bicarbonate concentration using serum total carbon dioxide concentration in patients with non-dialysis chronic kidney disease. Kidney Res Clin Pract. 2019, 38:326-335. 10.23876/j.krcp.19.027 
11. Hirai K, Ookawara S, Morino J, et al.: Relationship between serum total carbon dioxide concentration and bicarbonate concentration in patients undergoing hemodialysis. Kidney Res Clin Pract. 2020, 39:441-450. 10.23876/j.krcp.19.126

12. Lysaght MJ, Pollock CA, Hallet MD, Ibels LS, Farrell PC: The relevance of urea kinetic modeling to CAPD . ASAIO Trans. 1989, 35:784-790.

13. Watson PE, Watson ID, Batt RD: Total body water volumes for adult males and females estimated from simple anthropometric measurements. Am J Clin Nutr. 1980, 33:27-39. 10.1093/ajcn/33.1.27

14. Ramsay AG: Clinical application of the Henderson-Hasselbalch equation. Appl Ther. 1965, 7:730-736.

15. Vashistha T, Kalantar-Zadeh K, Molnar MZ, Torlén K, Mehrotra R: Dialysis modality and correction of uremic metabolic acidosis: relationship with all-cause and cause-specific mortality. Clin J Am Soc Nephrol. 2013, 8:254-264. 10.2215/CJN.05780612

16. Maas AH, van Heijst AN, Visser BF: The determination of the true equilibrium constant $(\mathrm{pK} 1 \mathrm{~g})$ and the practical equilibrium coefficient $(\mathrm{pK} 1 \mathrm{~g}$ ) for the first ionization of carbonic acid in solutions of sodium bicarbonate, cerebrospinal fluid, plasma and serum at 25 and 38. Clin Chim Acta. 1971, 33:325-343. 10.1016/0009-8981(71)90490-6

17. Kim Y, Massie L, Murata GH, Tzamaloukas AH: Discrepancy between measured serum total carbon dioxide content and bicarbonate concentration calculated from arterial blood gases. Cureus. 2015, 7:e398. 10.7759/cureus.398

18. Sarwar S, Sherman RA: How well does serum albumin correlate with dietary protein intake in dialysis patients?. Kidney Int Rep. 2017, 2:90-93. 10.1016/j.ekir.2016.09.004

19. Halperin ML, Jungas RL: Metabolic production and renal disposal of hydrogen ions. Kidney Int. 1983, 24:709-713. 10.1038/ki.1983.217

20. Raphael KL, Zhang Y, Ying J, Greene T: Prevalence of and risk factors for reduced serum bicarbonate in chronic kidney disease. Nephrology (Carlton). 2014, 19:648-654. 10.1111/nep.12315

21. Rossing TH, Maffeo N, Fencl V: Acid-base effects of altering plasma protein concentration in human blood in vitro. J Appl Physiol (1985). 1986, 61:2260-2265. 10.1152/jappl.1986.61.6.2260

22. Wu DY, Shinaberger CS, Regidor DL, McAllister CJ, Kopple JD, Kalantar-Zadeh K: Association between serum bicarbonate and death in hemodialysis patients: is it better to be acidotic or alkalotic?. Clin J Am Soc Nephrol. 2006, 1:70-78. 10.2215/CJN.00010505

23. Nagami GT: Hyperchloremia - why and how . Nefrologia. 2016, 36:347-353. 10.1016/j.nefro.2016.04.001

24. Mujais S: Acid-base profile in patients on PD . Kidney Int Suppl. 2003, 64:S26-36. 10.1046/j.15231755.2003.08803.x

25. Raja RM, Ijelu G, Goldstein M: Influence of Kt/V and protein catabolic rate on hemodialysis morbidity. A long-term study. ASAIO J. 1992, 38:M179-M180. 10.1097/00002480-199207000-00014

26. Tattersall JE, Dick C, Doyle S, Greenwood RN, Farrington K: Alkalosis and hypomagnesaemia: unwanted effects of a low-calcium CAPD solution. Nephrol Dial Transplant. 1995, 10:258-262. 10.1093/ndt/10.2.258 